\title{
Vicia cretica: a powerful lectin for T- and Th- but not Tk- or other polyagglutinable erythrocytes
}

\author{
GWG BIRD AND JUNE WINGHAM
}

From the Regional Blood Transfusion Service, Birmingham, West Midlands, B15 2SG, UK

SUMMARY Extracts of the seeds of Vicia cretica (NO Leguminosae) strongly agglutinate T- and Thbut not Tk- or other polyagglutinable red cells. The $V$. cretica lectin is therefore a very useful laboratory reagent in the elucidation of erythrocyte polyagglutination due to $\mathrm{T}$-like erythrocyte cryptantigens.

For many years the peanut (Arachis hypogaea) lectin ${ }^{1}$ has been of fundamental importance in the classification of red cell polyagglutinability. ${ }^{2}$ It strongly agglutinates T-, Th-, and Tk-polyagglutinable erythrocytes, which are distinguished from one another (Table) by tests with the soya bean (Glycine soja) and Bandeiraea simplicifolia (BS II) lectins.

\section{Material and methods}

Vicia cretica seeds were obtained from the Seed Bank of the Royal Botanic Gardens, Kew. Extracts were prepared and tested as described by Bird. ${ }^{3}$ Red cells were obtained from the comprehensive panel held in our laboratory. Agglutination tests were carried out by both tile and tube techniques. ${ }^{4}$

Normal group $\mathbf{O}$ erythrocytes were made Tkpolyagglutinable by the methods described by Doinel et al. ${ }^{5}$ with (1) a selected Bacteroides fragilis culture supernatant, and (2) a purified endo- $\beta$ galactosidase from Escherichia freundii, prepared by Dr MN Fukuda of Seattle.

Accepted for publication 14 July 1980

\section{Results}

$V$. cretica seed extract strongly and avidly agglutinates T- and Th-red cells, but not Tk- or those of other known forms of polyagglutinability. Proteasetreated cells are not agglutinated. Its reaction on Ttransformed red cells is as powerful as that of the peanut lectin. Its avidity for Th-erythrocytes was consistently greater than that of the peanut lectin. It failed to agglutinate Tk-polyagglutinable cells (without concomitant T-transformation) even after the cells had been treated with papain, which enhances Tk. The reactions obtained with $V$. cretica seed extract and with other lectins relevant to the classification of $\mathrm{T}$-like erythrocyte receptors are given in the Table.

\section{Discussion}

Other lectins known to agglutinate T-transformed cells include Tephrosia hookeriana, Thermopsis caroliniana, and Thermopsis montana. ${ }^{6}$ These lectins are, however, inferior to the peanut lectin, whereas the $V$. cretica lectin is as powerful. $V$. cretica is indigenous to Crete and eastern Greece; its seeds are

Interaction of $T$ and $T$-like erythrocytes with a select panel of lectins

\begin{tabular}{llllll}
\hline Lectins & Red cells & & & & \\
\cline { 2 - 6 } & T & Tk (B. fragilis) & Tk (E. freundii) & Th & Protease-treated \\
\hline $\begin{array}{llll}\text { Arachis hypogaea } \\
\text { Glycine soja }\end{array}$ & +++ & +++ & - & +++ & - \\
BS II* & ++ & - & +++ & - & ++ \\
Vicia cretica & +++ & - & ++ & +++ & - \\
\hline
\end{tabular}

*A second isolectin from Bandeiraea simplicifolia. 
not as easy to obtain as peanuts. The $V$. cretica lectin is therefore unlikely to replace the peanut lectin in routine laboratory investigation of erythrocyte polyagglutinability, but we have no doubt that the $V$. cretica lectin will fulfil a very useful role in specialised laboratories in the investigation of red cell polyagglutinability.

We are indebted to Mr TCF Roy for expert help, to Mr G Inglis and Dr AAB Mitchell for Bacteroides fragilis culture supernatants, and to Dr MN Fukuda for the endo- $\beta$-galactosidase from Escherichia freundii.

\section{References}

${ }^{1}$ Bird GWG, Wingham J. Anti-T in peanuts. Vox Sang 1964;9:748-9.
2 Bird GWG. Lectins specific for human red cell antigens. In: Peeters H, ed. Protides of Biological Fluids. 27th Colloquium 1979. Oxford: Pergamon Press, 1980;515-20.

${ }^{3}$ Bird GWG. Erythrocyte agglutinins from plants. $\mathrm{PhD}$ thesis, London: 1958

* Bird GWG, Wingham J. Agglutination and agglutinationinhibition. In:Thompson RA, ed. Techniques in Clinical Immunology. Oxford: Blackwell, 1977;43-64.

${ }^{5}$ Doinel C, Andreu G, Cartron JP, Salmon C, Fukuda MN. Tk polyagglutination produced in vitro by an endo-betagalactosidase. Vox Sang 1980;38:94-8.

${ }^{6}$ Bird GWG. Erythrocyte polyagglutination. Nouv Rev Fr Hémat $1971 ; 11: 885-96$

Requests for reprints to: Dr GWG Bird, Regional Blood Transfusion Centre, Vincent Drive, Edgbaston, Birmingham B15 2SG. 